\title{
EFFECT OF STALK AND LEAF EXTRACTS FROM EUPHORBIACEAE SPECIES ON Aedes aegypti (DIPTERA, CULICIDAE) LARVAE
}

\begin{abstract}
SUMMARY
The objective of this study was to evaluate the larvicidal activity of essential oil aqueous solutions (hydrolates) obtained by steam distillation of stalks and leaves of Croton argyrophylloides, Croton nepetaefolius, Croton sonderianus and Croton zehntneri against Aedes aegypti larvae. Twenty-five larvae of third instar were placed in plastic beckers, containing the hydrolates (50 mL), in a four repetitions scheme. Water was used as control and the number of dead larvae was counted after 24 hours. The data obtained were submitted to Variance Analysis and Tukey test. Significant differences were observed among the hydrolates from different species and from different parts of each plant $(\mathrm{p}<0.001)$. The hydrolates of stalk and leaf from C. nepetaefolius and $C$. zehntneri and leaf hydrolate of $C$. argyrophylloides presented $100 \%$ mortality against larvae. The compounds present in $C$. zenhtneri and C. nepetaefolius are oxygenated phenylpropanoids that are more soluble in water than the monoterpenes and sesquiterpenes detected in the oils of $C$. argyrophylloides and $C$. sonderianus. This study showed that all species analyzed presented compounds with larvicidal properties, with differences between each plant parts.
\end{abstract}

KEYWORDS: Aedes aegypti, Hydrolates, Larvicidal activity, Euphorbiaceae, Croton.

\section{INTRODUCTION}

Dengue fever is a viral infection transmitted by mosquitoes of genus Aedes and is considered one of the most important problems to the world public health. This disease presents high incidence in tropical and subtropical countries and it is estimated that approximately 1,3 billion people are at risk to be infected by the dengue fever virus ${ }^{19}$. $A$. aegypti is the principal insect responsible for dengue fever transmission in the tropical countries. In America, this insect promotes frequent epidemics and there was a spreading of the four serotypes of the virus in the continent ${ }^{5}$.

Several cases of resistance have been reported in the world for vector mosquito species, and particularly for the population of A. aegypti in Brazil. There are reports of occurrence of resistance to organophosphorates at least in eight cities of São Paulo State with detection of resistance against temephos ${ }^{2,10}$.

The great diversity of plants in Brazil is represented by 550,000 species ${ }^{14}$ and studies with plant extracts show the expectation of finding substances with insecticide properties and simultaneously selective to be used in future formulas of commercial products. The hydrolates are aqueous solutions obtained as by-products of the essential oil steam distillation process, using a Clevenger type apparatus ${ }^{6}$. They contain as main constituents the most hydrophylic compounds present in the essential oils.

Various studies showed the activity of plant extracts against different species of mosquitoes ${ }^{8,11,12}$ including $A$. aegypti $i^{9,15,17}$. The present study aimed to determine and evaluate the larvicidal effect of hydrolates obtained from stalk and leaves of Croton argyrophylloides, Croton nepetaefolius, Croton sonderianus and Croton zehntneri against third instar larvae of A. aegypti.

\section{MATERIAL AND METHODS}

Plant species: The selected plants of this research were native species from Ceará State, situated in northeast of Brazil and were collected in Viçosa city. Voucher specimens were deposited in Prisco Bezerra Herbarium of Federal University of Ceará under the following numbers: for C. argyrophylloides Muell. Arg. (Marmeleiro prateado) 32444, for C. nepetaefolius Baill (Marmeleiro sabiá) - 32448; $C$. sonderianus Muell. Arg. (Marmeleiro preto) - 32445 and for $C$. zehntneri Pax \& Hoffm (Canela de cunhã) - 32446. The hydrolates were obtained from stalk and leaves of the plants.

Extraction of hydrolates: The part plants were submitted to steam distillation in a Clevenger-type apparatus ${ }^{6}$. The steam passes through

(1) Curso de Ciências Biológicas da Universidade Estadual do Ceará, Fortaleza, CE, Brasil.

(2) Laboratório de Produtos Naturais da Universidade Estadual do Ceará, Fortaleza, CE, Brasil.

(3) Departamento de Estatística e Matemática Aplicada da Universidade Federal do Ceará, Fortaleza, CE, Brasil.

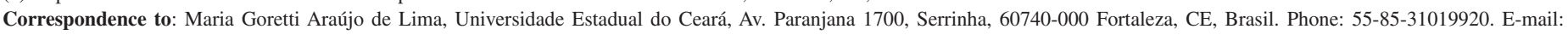
goretti@uece.br 


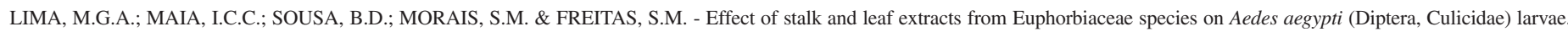
Rev. Inst. Med. trop. S. Paulo, 48(4): 211-214, 2006.

a condenser and is collected into a separator. A biphasic mixture is formed by the essential oil in the superior phase and the aqueous phase, which is separated through decantation. The water that remains after the process of oil extraction is called hydrosol or hydrolate; it contains many bioactive compounds and the plant therapeutic properties ${ }^{7}$.

Essential oil analysis: The oils were analysed using a HewlettPackard 5971 GC/MS instrument employing the following conditions: column: Dimethylpolysiloxane DB-1 coated fused silica capillary column (30 mm x $0.25 \mathrm{~mm})$; carrier gas: $\mathrm{He}(1 \mathrm{~mL} / \mathrm{min})$; injector temperature: $250{ }^{\circ} \mathrm{C}$; detector temperature: $200{ }^{\circ} \mathrm{C}$; column temperature: $35^{\circ} \mathrm{C}-180{ }^{\circ} \mathrm{C}$ at $4{ }^{\circ} \mathrm{C} / \mathrm{min}$ then $180{ }^{\circ} \mathrm{C}-250{ }^{\circ} \mathrm{C}$ at $10{ }^{\circ} \mathrm{C} /$ min; mass spectra: electron impact $70 \mathrm{eV}$. The identification of the constituents was performed by computer library search, retention indices and visual interpretation of the mass spectra $^{1,7}$.

Bioassays: Larvae of $A$. aegypti were obtained from a five years old colony, maintained under controlled conditions, $27-30{ }^{\circ} \mathrm{C}$ of temperature, $75-80 \%$ of relative humidity and the light-dark cycle at 12 hours of light followed by 12 hours of darkness. This colony belonged to the Laboratory of Entomology of the Endemic Diseases Unit from Health Secretary in Ceará State (NUEND/SESA). Third instar larvae were collected by direct pipeting from a previous flask and carefully washed. Then they were removed from water by filtration and 25 larvae were transferred to the test flask that contained the hydrolates $(50 \mathrm{~mL})$.

The control was distilled water, with an experimental design made totally at random, following a factorial scheme of $4 \times 2$ (hydrolates $\mathrm{x}$ plant parts), with four repetitions, comprising 100 larvae for each treatment.

The evaluation of mortality rate was performed 24 hours after the beginning of the experiment, verifying the number of dead larvae. The larvae were considered dead when they did not present movement and did not respond to stimulus with a Pasteur pipette. The environmental temperature and humidity were observed during the experiment, with variation between $27^{\circ} \mathrm{C}-30^{\circ} \mathrm{C}$.

Statistical analysis: The data were submitted to angular transformation ${ }^{13}$ to follow the conditions of normality of the distribution of responses and homogeneity of the variance among the treatments to enable the performance of Variance Analysis. Dunnet test to multiple comparisons was used between the plant parts.

\section{RESULTS}

The concentration of the leaf essential oil in each hydrolate differ: C. nepetaefolius $-8.3 \%$, C. zehntneri $-7.8 \%$, C. argyrophyloides $-4 \%$ and $C$. sonderianus $-4.6 \%$. The stalk and leaves hydrolates of $C$. nepetaefolius and C. zehntneri induced $100 \%$ mortality to larvae. The hydrolates of $C$. argyrophyloides and $C$. sonderianus presented variations on larvicidal potential for different tested plant parts. The hydrolate of $C$. argyrophyloides stalk induced 54\% mortality while the leaf hydrolate promoted $100 \%$ mortality. The hydrolate of $C$. sonderianus stalk induced $8 \%$ mortality while leaf hydrolate and promoted $52 \%$ of mortality rate to larvae (Fig. 1). Almost all treatments tested differed significantly $(\mathrm{p}<0.001)$ to control, with exception for the hydrolate of $C$. sonderianus stalk, which promoted low mortality, and did not differ to group control, which presented no mortality to $A$. aegypti larvae $(\mathrm{p}>0.05)$. C. sonderianus and C. argyrophylloides hydrolates showed statistic differences activities for stalk and leaf, suggesting that different active properties are distributed in these plant parts or the same active property is present in different concentrations. However, the stalk and leaf hydrolates of $C$. zehntneri and $C$. nepetaefolius did not present results with statistically significance, indicating the possibility that the active principle is distributed equally in the tested parts.

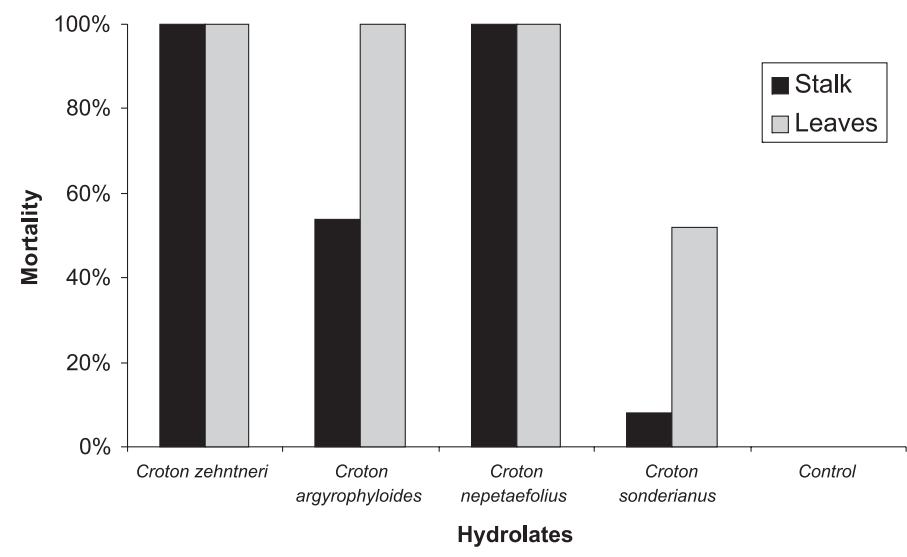

Fig. 1 - Mortality of A. aegypti larvae as response to 24 hours treatment to different plant hydrolates. Fortaleza, CE, 2004.

\section{DISCUSSION}

According to VIEIRA et al. (2001) ${ }^{18}$, terpenoids, especially lemonoids (tetranortriterpenes), are the major examples of insecticide substances, however simple monoterpenes also perform protection against insects in the plants, demonstrating good insecticide activity in experimental models. Various other compounds as diterpenes, nortriterpenes and sesquiterpenes are reported as phagoinhibitors and growth inhibitors (blocking the development of ecdyses) to many types of insects. Reports about the larvicidal action against A. aegypti of $C$. nepetaefolius, C. zehntneri, C. argyrophyloides and C. sonderianus, species used in this study, were not found in the literature. CARVALHO et al. $(2003)^{3}$ demonstrated the larvicidal activity of pure and diluted hydrolate of Lippia sidoides Cham. and the principal component of leaf essential oil, thymol, against $A$. aegypti. The hydrolate induced mortality almost instantaneous to the larvae while thymol induced $100 \%$ mortality with $0.017 \%(\mathrm{w} / \mathrm{v})$ of concentration at 1.5 hour of experiment. A study conducted with essential oil components revealed that the more active compounds against $A$. aegypti are phenylpropanoids and sesquiterpene alcohols ${ }^{16}$. The larvicidal activity of essential oils from Northeastern Brazilian plants showed good results for Ocimum americanum with $\mathrm{LC}_{50} 67 \mathrm{ppm}$ and Ocimum gratissimum $\mathrm{LC}_{50} 60 \mathrm{ppm}$. The main components in these oils were $E$-methyl-cinnamate and eugenol both phenylpropanoid derivatives ${ }^{4}$.

The composition of the leaf essential oils of these Croton species is displayed in Table 1. The main constituents of $C$. zenhtneri oil was anethole and estragole and $C$. nepetaefolius presented as major components methyleugenol that are oxygenated compounds and 
Table 1

Main constituents of essential oils from Croton species

\begin{tabular}{|c|c|c|c|c|c|}
\hline \multirow[t]{2}{*}{${ }^{\mathrm{a}}$ Constituents } & \multirow[t]{2}{*}{${ }^{\mathrm{b}} \mathrm{KI}$} & \multicolumn{4}{|c|}{${ }^{c}$ Essential oils } \\
\hline & & $\mathrm{Cz}$ & $\mathrm{Cn}$ & $\mathrm{Ca}$ & Cs \\
\hline$\alpha$-Pinene & 939 & 0.78 & 3.55 & 20.96 & 10.49 \\
\hline Camphene & 954 & - & 1.53 & - & - \\
\hline$\beta$-Pinene & 974 & - & 1.28 & 9.55 & 1.37 \\
\hline Sabinene & 975 & - & - & 3.82 & - \\
\hline Myrcene & 991 & 1.18 & - & - & 1.86 \\
\hline$o$-Cimene & 1026 & - & - & - & - \\
\hline$\beta$-Phelandrene & 1030 & & & & 18.21 \\
\hline 1,8-Cineole & 1032 & 0.59 & - & 1.71 & - \\
\hline$\delta$-Elemene & 1338 & - & - & 1.17 & - \\
\hline$\gamma$-Terpinene & 1062 & - & - & - & 0.86 \\
\hline Terpinolene & 1089 & - & - & - & 1.21 \\
\hline 4-terpineol & 1177 & - & - & - & 0.49 \\
\hline Estragole & 1196 & 0.46 & - & - & - \\
\hline O-Methyltimol & 1235 & - & - & - & - \\
\hline trans-Anetol & 1284 & 94.09 & - & 0.62 & - \\
\hline Thymol & 1290 & - & - & - & - \\
\hline$\delta$-Elemene & 1338 & - & - & - & 1.24 \\
\hline$\alpha$-Cubebene & 1351 & - & 1.38 & - & 0.48 \\
\hline$\alpha$-Copaene & 1377 & - & 19.87 & - & - \\
\hline Cyperene & 1379 & - & - & - & 2.48 \\
\hline$\beta$-Cubebene & 1388 & - & 2.28 & - & - \\
\hline$\beta$-Elemeno & 1391 & - & 1.93 & 5.68 & 1.14 \\
\hline Methyleugenol & 1404 & - & 48.47 & - & - \\
\hline Trans-Caryophyllene & 1421 & 1.96 & 5.44 & 8.95 & 10.38 \\
\hline$\beta$-Gurjunene & 1434 & - & - & - & 1.30 \\
\hline$\alpha$-Guaiene & 1440 & - & 3.31 & - & - \\
\hline Aromadendrene & 1441 & - & - & 1.04 & 2.61 \\
\hline Bicyclogermacrene & 1488 & - & 1.51 & - & - \\
\hline$\gamma$-Muurolene & 1480 & - & - & - & 9.86 \\
\hline$\alpha$-Humulene & 1455 & - & - & 1.92 & 4.19 \\
\hline Epibicyclosesquiphellandrene & 1460 & - & - & 2.59 & - \\
\hline Alloaromadendrene & 1460 & - & - & 1.54 & 2.57 \\
\hline$\beta$-trans-Guaiene & 1503 & - & - & 15.97 & 16.5 \\
\hline$\delta$-Cadinene & 1523 & - & 3.97 & 1.27 & 2.48 \\
\hline$\gamma$-Cadinene & 1514 & - & - & 0.88 & 0.6 \\
\hline$\alpha$-Cadinene & 1539 & - & - & 1.55 & 0.94 \\
\hline Spathulenol & 1578 & - & - & 0.85 & 1.0 \\
\hline Caryophyllene oxide & 1583 & - & 1.52 & - & - \\
\hline$\beta$-Bisabolene & 1770 & - & - & 1.47 & - \\
\hline
\end{tabular}

$a$ : the compounds are displayed in order of elution from a non polar column, $b$ : retention indices in the chromatographic column, $c$ : symbols represent the first letters of botanical names (Cz: Croton zenhtneri; $\mathrm{Cn}$ : Croton nepetaefolius; $\mathrm{Ca}$ : Croton argyrophylloides, Cs: Croton sonderianus).

explains the higher percentage of these oils in the respective hydrolates when compared to other two Croton species. C. argyrophylloides showed as main constituents the monoterpenes $\alpha$-pinene and $\beta$-pinene, that are considered good larvicidal agents ${ }^{16} . C$. sonderianus presented the hydrocarbons $\alpha$-pinene, $\beta$-phelandrene (monoterpenes) and transcaryophyllene (sesquiterpenes) as main constituents. The hydrocarbons are lesser soluble in water than oxygenated compounds therefore the lower solubility of active ingredients also account to the differences in the activity of the hydrolates.

In conclusion, despite the compounds detected in the essential oils of these plant species, the hydrolates consist of a water solution that contains the most hydrophyllic compounds, which can be responsible for the mortality of $A$. aegypti larvae. The compounds present in $C$. zenhtneri and C. nepetaefolius are oxygenated phenylpropanoids that are more soluble in water than the monoterpenes and sesquiterpenes detected in the oils of $C$. argyrophylloides and $C$. sonderianus. The hydrolates in Brazilian essential oil producers are obtained in larger amounts in relation to the respective essential oils, therefore they represent an important and viable alternative, since they are produced in superior quantities through the same method of production.

\section{RESUMO}

Efeito dos extratos de caule e folha de espécies de Euphorbiaceae sobre larvas de Aedes aegypti (Diptera, Culicidae)

O objetivo deste trabalho foi avaliar a atividade larvicida dos hidrolatos obtidos por destilação à vapor de caule e folha das espécies de Croton argyrophylloides, Croton nepetaefolius, Croton sonderianus e Croton zehntneri contra Aedes aegypti. Em cada bioensaio foram utilizadas 25 larvas de $3^{\circ}$ estádio juntamente com $50 \mathrm{~mL}$ de cada hidrolato, dispostos em recipientes plásticos, num esquema de quatro repetições, utilizando-se como controle a água e avaliando-se a mortalidade com 24 horas de tratamento. Os dados foram submetidos à análise de variância e ao teste de Tukey. Verificou-se que houve diferença significativa tanto em relação aos hidrolatos das diferentes espécies vegetais, quanto em relação às diferentes partes de cada planta ( $\mathrm{p}<0,001)$. Os hidrolatos referentes ao caule e folha de C. nepetaefolius e C. zehntneri causaram $100 \%$ de mortalidade das larvas e diferiram das demais espécies, exceto da folha do C. argyrophylloides que apresentou o mesmo resultado. Os compostos presentes em C. zehntneri e C. nepetaefolius são fenil propanóides mais solúveis em água que os monoterpenos e sesquiterpenos detectados em C. argyrophylloides e C. sonderianus. Esta pesquisa evidenciou que todas as espécies testadas possuem compostos com propriedades larvicidas, com diferenças entre as partes da planta analisadas.

\section{ACKNOWLEDGEMENTS}

The authors thank the Conselho Nacional de Desenvolvimento Científico e Tecnológico (CNPq) for the scholarships and to Núcleo de Endemias da Secretaria de Saúde do Estado do Ceará for their collaboration in grain processing.

\section{REFERENCES}

1. ADAMS, R.P. - Identification of essential oil components by gas chromatography/ quadrupole mass spectroscopy. Illinois, Allured, 2001. 455p.

2. ANDRADE, C.F.S. \& MODOLO, M. - Susceptibility of Aedes aegypti larvae to temephos and Bacillus thuringiensis var. israelensis in integrated control. Rev. Saúde públ. (S. Paulo), 25: 184-187, 1991.

3. CARVALHO, A.F.U.; MELO, V.M.N.; CRAVEIRO, A.A. et al. - Larvicidal activity of the essencial oil from Lippia sidoides Cham. against Aedes aegypti Linn. Mem. Inst. Oswaldo Cruz, 98: 569-571, 2003. 


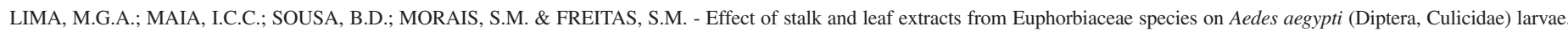
Rev. Inst. Med. trop. S. Paulo, 48(4): 211-214, 2006.

4. CAVALCANTI, E.S.B; MORAIS, S.M.; LIMA, M.A.A. \& SANTANA, E.W.P. Larvicidal activity of essential oils from Brazilian plants against Aedes aegypti L. Mem. Inst. Oswaldo Cruz, 98: 541-544, 2004.

5. CIVES. Centro de Informação em Saúde para Viajantes - Dengue. Available at: www.cives.ufrj.br/informacao/dengue/den-iv.html. Accessed on 14 February, 2002.

6. CRAVEIRO, A.A.; MATOS, F.J.A. \& ALENCAR, J.W. - A simple and inexpensive steam generator for essential oils extraction. J. Chem. Ed., 5: 652, 1976.

7. CRAVEIRO, A.A.; FERNANDES, A.G.; ANDRADE, C.H.S. et al. - Óleos essenciais de plantas do nordeste. Fortaleza, 1981.

8. GUIMARÃES, V.P.; SILVA, I.G.; SILVA, H.H.G. \& ROCHA, C. - Atividade larvicida do extrato bruto etanólico da casca do caule de Magonia pubescens St. Hil. sobre Aedes albopictus (Skuse, 1894) (Diptera, Culicidae). Rev. Pat. trop., 30: 243-249, 2001.

9. GUSMÃO, D.S.; PASCOA, V.; MATHIAS, L. et al - Derris (Lonchocarpus) urucu (Leguminosae) extract modifies the peritrophic matrix structure of Aedes aegypti (Diptera: Culicidae). Mem. Inst. Oswaldo Cruz, 97: 371-375, 2002.

10. MACORIS, M.L.G.; ANDRIGHETTI, M.T.; TAKAKU, L. et al - Alteração da resposta de susceptibilidade de Aedes aegypti a inseticidas organofosforados em municípios do Estado de São Paulo, Brasil. Rev. Saúde públ. (S. Paulo), 33: 521-522, 1999.

11. MARKOUK, M.; BEKKOUCHE, K.; LARHSINI, M. et al. - Evaluation of some Moroccan medicinal plant extracts for larvicidal activity. J. Ethnopharm., 73: 293297, 2000.

12. RAHUMAN, A.A.; GOPALAKRISKNAN, G.; GHOUSE, B.S.; ARUMUGAM, S. \& HIMALAYAN, B. - Effect of Feronia limonia on mosquito larvae. Fitoterapia, 71: $553-555,2000$
13. SAMPAIO, I.M.B. - Estatística aplicada à experimentação animal. Belo Horizonte, Fundação de Ensino e Pesquisa em Medicina Veterinária e Zootecnia, 1998.

14. SANDES, A.R.R. \& BLASI, G. - Biodiversidade e diversidade química e genética. Biotecnologia: ciência e desenvolvimento, 13: 28-37, 2000.

15. SILVA, H.H.G.; SILVA, I.G.; SANTOS, R.M.G.; RODRIGUES FILHO, E. \& ELIAS, C.N. - Larvicidal activity of tannins isolated of Magonia pubescens St. Hil. (Sapindaceae) against Aedes aegypti (Diptera, Culicidae). Rev. Soc. bras. Med. trop. 37: 396-399, 2004

16. SIMAS, N.K.; LIMA, E.C.; CONCEIÇÃO, S.R.; KUSTER, R.M. \& OLIVEIRA FILHO, A.M. - Produtos naturais para o controle da transmissão da dengue: atividade larvicida de Myroxylon balsamum (óleo vermelho) e de terpenóides e fenilpropanóides. Quím. nova, 27: 46-49, 2004.

17. TSAO, R.; ROMANCHUK, F.E.; PETERSON, C.J. \& COATS, J.R. - Plant grown regulatory effect and insecticidal activity of the extracts of the tree of heaven (Ailanthus altisssima L.). BMC Ecol., 2: 1, 2002.

18. VIEIRA, P.C.; MAFEZOLI, J. \& BIAVATTI, M.W. - Inseticidas de origem vegetal. In: FERREIRA, J.T.B.; CORRÊA, A.G. \& VIEIRA, P.C. Produtos naturais no controle de insetos. São Carlos, Editora da Universidade Federal de São Carlos, 2001. (Série de textos da Escola de Verão em Química, v. III).

19. WORLD HEALTH ORGANIZATION - Impact of dengue, 2001. Available at: http:// www.who.int/csr/disease/dengue/impact/en/index.html. Accessed on 18 March de 2002.

Received: 12 April 2005

Accepted: 9 May 2006 